\title{
First record of Aphidius ericaphidis (Hymenoptera, Braconidae) in Europe: North American hitchhiker or overlooked Holarctic citizen?
}

\author{
Andjeljko Petrović', Jelisaveta Čkrkić', Aiman Jamhour', Olivera Petrović-Obradović2, \\ Milana Mitrovićs ${ }^{3}$ Petr Starý, $\dot{y}^{4}$ Barbro Nedstam ${ }^{5}$, Željko Tomanović
}

I Institute of Zoology, Faculty of Biology, University of Belgrade, Studentski trg 16, 11000 Belgrade, Serbia 2 Department of Plant Protection, Faculty of Agriculture, University of Belgrade, Nemanjina 6, 11081 Zemun, Serbia 3 Department of Plant Pests, Institute for Plant Protection and Environment, Banatska 33, 11080 Zemun, Serbia 4 Laboratory of Aphidology, Institute of Entomology, Biology Centre, Academy of Sciences of the Czech Republic, Branišovská 31, 37005 České Budějovice, Czech Republic 5 Plant Protection Centre, Swedish Board of Agriculture, Alnarp, Sweden (ret.)

Corresponding author: Andjeljko Petrović (andjeljko@bio.bg.ac.rs)

Academic editor: J. Fernandez-Triana | Received 3 March 2017 | Accepted 21 April 2017 | Published 30 June 2017

http:I/zoobank.org/1F9074E9-6DC6-4326-A392-727C492E5F2F

Citation: Petrović A, Čkrkić J, Jamhour A, Petrović-Obradović O, Mitrović M, Starý P, Nedstam B, Tomanović Ž (2017) First record of Aphidius ericaphidis (Hymenoptera, Braconidae) in Europe: North American hitchhiker or overlooked Holarctic citizen? Journal of Hymenoptera Research 57: 143-153. https://doi.org/10.3897/jhr.57.12517

\begin{abstract}
Aphidius ericaphidis, an aphid parasitoid originally described from North America, is recorded in Europe for the first time, based on morphological and molecular analyses. The species is recorded in Serbia, the Netherlands, Sweden and the United Kingdom. It was formerly recorded as Aphidius sp./Ericaphis latifrons/Vaccinium uliginosum from the Alps (France). The possible origin of A. ericaphidis, as well as its likely distribution, is discussed in relation to its host. As it is a specific parasitoid of Ericaphis aphids, especially the invasive aphid Ericaphis scammelli on blueberries, its potential as a biocontrol agent is also discussed.
\end{abstract}

\section{Keywords}

Alien species, Aphidius ericaphidis, Ericaphis scammelli, blueberries, biological control

Copyright Andjeljko Petrović et al. This is an open access article distributed under the terms of the Creative Commons Attribution License (CC BY 4.0), which permits unrestricted use, distribution, and reproduction in any medium, provided the original author and source are credited. 


\section{Introduction}

Growing of highbush blueberry started with the experiments of Coville (1910) in the first decade of the $20^{\text {th }}$ century in the United States. The first successful attempts to grow blueberries in Europe were made in Germany in the 1930s (Heermann 1932). They resulted in the first commercial plantation of 50 ha in 1951 (Pliszka 1997). World blueberry production has been significantly expanding in recent years, owing to the fruit's numerous health benefits. Between 1994 and 2014, the world area under commercial blueberries almost doubled, while production rose four times (FAOSTAT Database). With their high antioxidant capacity, long shelf life and minimal preparation prior to consumption, blueberries are considered a "superfruit" (Clarke 2016).

One of the economically most important blueberry pathogens is the blueberry scorch virus $(\mathrm{BIScV})$, which was first observed in Washington, USA, in commercial blueberry fields (Martin and Bristow 1988). After that it was reported in British Columbia, Canada (Hudgins 2000) and has since spread to Europe (Ciuffo et al. 2005, Paduch-Cichal et al. 2011, Richert-Pöggeler et al. 2015, EPPO 2016). Most of the records are from the commercially grown highbush blueberry (Vaccinium corymbosum L.), and according to EPPO there are still no data on the susceptibility of native European Vaccinium species (EPPO 2005). Symptoms caused by BlScV differ depending on the cultivar of blueberry. In sensitive cultivars, infection can lead to complete necrosis (blighting) of flowers and young leaves and twig dieback followed by severe yield loss, while tolerant cultivars can show little or no visible symptoms of infection (Bristow et al. 2000, Martin et al. 2012).

The blueberry scorch virus is transmitted mainly by Ericaphis fimbriata (Richards) in a nonpersistent manner (Bristow et al. 2000). Ericaphis fimbriata is probably synonymous with E. scammelli (Mason), based on morphological and molecular analyses (Blackman and Eastop 1984, Foottit et al. 2008, G. Bosio - pers. comm. 2001, V. Eastop - pers. comm. 2002) and will be referred to as E. scammelli in this paper. The aphid is most likely native to North America and was probably introduced into Europe with plant material (Barbagallo et al. 1998), with the first record for Europe from the UK in 1964 (Cour d'acier et al. 2010). In Britain it was described as E. fimbriata ssp. pernettyae, monoecious holocyclic on Pernettya mucronata but probably also holocyclic on Vaccinium species (Prior 1971), Italian populations are referred to as E. scammelli and are monoecious holocyclic on Vaccinium spp. (Blackman and Eastop 1984, Barbagallo et al. 1998, Pansa and Tavela 2008). Besides those two countries, it has also been recorded in the Netherlands, France (Nieto Nafria 2013) and Sweden (Nedstam 2008).

The braconid parasitoid complex of E. scammelli $(=$ E. fimbriata) in North America consists of 10 species (Hymenoptera: Aphidiinae), among which the most common are Praon unicum Smith, 1944 and Aphidius ericaphidis Pike \& Starý, 2011 (Raworth et al. 2008, Pike et al. 2011, Mathur et al. 2013). Here we present the first records of A. ericaphidis from Europe and discuss its potential as a biocontrol agent in European blueberry orchards. 


\section{Methods}

During the last several years, the Aphidiinae fauna on different fruit species was investigated throughout Europe. Samples of Vaccinium spp. leaves with aphids and mummies were collected. The samples were kept under laboratory conditions until parasitoid emergence. After emergence, parasitoids were immersed in 96\% ethanol and preserved for later examination. External morphology of the specimens was studied using a ZEISS Discovery V8 stereomicroscope. Scanning electron micrographs were obtained using a JEOL JSM-6390 scanning electron microscope. All specimens are deposited in the collection of the Institute of Zoology, Faculty of Biology, University of Belgrade and the collection of P. Starý, České Budějovice, Czech Republic.

\section{Molecular analysis}

Three A. ericaphidis specimens from Scotland were used for molecular analysis. DNA was extracted from individual adult wasps using the Qiagen DNeasy Blood \& Tissue Kit (Qiagen Inc., Valencia, CA) following the manufacturer's instructions. The barcoding region of the mitochondrial cytochrome oxidase subunit I (COI) gene was amplified using the primers LCO1490 and HCO2198 (Folmer et al. 1994).

DNA amplification was performed in a final volume of $20 \mu \mathrm{l}$ containing $1 \mu \mathrm{l}$ of DNA, $11.8 \mu \mathrm{l}$ of $\mathrm{H}_{2} \mathrm{O}, 2 \mu \mathrm{l}$ of High Yield Reaction Buffer A with $1 \times \mathrm{Mg}, 1.8 \mu \mathrm{l}$ of $\mathrm{MgCl}_{2}(2.25$ $\mathrm{mM}), 1.2 \mu \mathrm{l}$ of dNTP $(0.6 \mathrm{mM}), 1 \mu \mathrm{l}$ of each primer $(0.5 \mu \mathrm{M})$ and $0.2 \mu \mathrm{l}$ of KAPATaq DNA polymerase $(0,05 \mathrm{U} / \mu \mathrm{l})$ (Kapa Biosystems Inc., USA). PCR was conducted in an Eppendorf Mastercycler (Hamburg, Germany) using the following thermal profile: initial denaturation at $95^{\circ} \mathrm{C}$ for $5 \mathrm{~min}$, followed by 35 cycles of $94^{\circ} \mathrm{C}$ for $60 \mathrm{~s}, 54^{\circ} \mathrm{C}$ for $60 \mathrm{~s}$, $72^{\circ} \mathrm{C}$ for $90 \mathrm{~s}$ and a final extension step at $72^{\circ} \mathrm{C}$ for $7 \mathrm{~min}$. Purification of PCR products and DNA sequencing in both directions was performed by Macrogen Inc. (Seoul, Korea).

Sequences of $A$. ericaphidis specimens from North America and other Aphidius species were obtained from GenBank and used in phylogenetic analysis. Those Aphidius species were chosen because of their morphological similarity to A. ericaphidis or because they parasitize E. scammelli. An Ephedrus sp. sequence from GenBank (acc. number KR787408) was used as an outgroup taxon. Sampling data for specimens used in this study are given in Table 1.

Sequences were edited using FinchTV ver 1.4.0 (http://www.geospiza.com). Alignment was conducted using CLUSTAL W integrated in MEGA 5 software (Tamura et al. 2011). Sequences were trimmed to a length of $611 \mathrm{bp}$. The sequences of analysed $A$. ericaphidis specimens were deposited in GenBank under accession numbers KY513289KY513291. Calculation of average genetic distances between sequences was performed using Kimura's two-parameter method (K2P) of base substitution (Kimura 1980).

A phylogenetic tree was constructed using the MEGA 5 software (Tamura et al. 2011) and the Maximum likelihood method with 1000 bootstrap replicates. 
Table I. Sampling data for Aphidiinae specimens used in the molecular analysis.

\begin{tabular}{l|l|l|l|l|c}
\hline \multicolumn{1}{c|}{ Parasitoid } & Code & Geographic origin & \multicolumn{1}{c|}{ Aphid host } & \multicolumn{1}{c|}{ Plant } & $\begin{array}{c}\text { Accession } \\
\text { number }\end{array}$ \\
\hline Aphidius ericaphidis & IM50 & Scotland & Ericaphis scammelli & Vaccinium corymbosum & KY513289 \\
\hline Aphidius ericaphidis & IM51 & Scotland & Ericaphis scammelli & Vaccinium corymbosum & KY513290 \\
\hline Aphidius ericaphidis & IM52 & Scotland & Ericaphis scammelli & Vaccinium corymbosum & KY513291 \\
\hline Aphidius ericaphidis & & Canada/USA & Ericaphis fimbriata & Vaccinium corymbosum & KC211024 \\
\hline Aphidius ericaphidis & & Canada/USA & Ericaphis fimbriata & Vaccinium corymbosum & EU574902 \\
\hline Aphidius avenaphis & & USA & Sitobion avenae & Triticum aestivum & JN164784 \\
\hline Aphidius matricariae & & Canada & & & KR888554 \\
\hline Aphidius urticae & & UK & & & JX507436 \\
\hline Aphidius ervi & & Canada/USA & & & KC211026 \\
\hline Ephedrus sp. & & & & & KR787408 \\
\hline
\end{tabular}

\section{Results}

Aphids infesting Vaccinium corymbosum in Serbia, Sweden and Scotland were identified as E. scammelli. Rearing parasitoids from E. scammelli resulted in finding the species A. ericaphidis for the first time in Europe. Aphidius ericaphidis is recorded in Serbia, Sweden and the United Kingdom (Scotland). Additional re-examination of collections (P. Starý) led to identification of A. ericaphidis in France and the Netherlands as well, the re-examined specimens from both countries having been previously identified as Aphidius sp. (Starý et al. 1971, P. Starý unpubl.). In total 24 females and 19 males were found.

As the original differential diagnosis of $A$. ericaphidis referred to North American congeners (Pike et al. 2011), it is advisable to relate it also to those in Europe as follows: Aphidius ericaphidis (Fig. 1) is most similar to Aphidius matricariae Haliday 1834. It can be easily distinguished from the latter by the number of maxillary and labial palpomeres [A. matricariae has 3-segmented maxillary palps and 2-segmented labial palps vs. 4-segmented maxillary palps and 3-segmented labial palps in A. ericaphidis] and by pterostigma length $/ \mathrm{R} 1$ forewing vein ratio $[A$. matricariae $=1.1($ range $1-1.2)$ vs. A ericaphidis $=2.1$ (range 1.7-2.7)].

\section{Aphidius ericaphidis}

Fig. 1

Serbia, Mladenovac, 10 VI 2015, 7 females and 4 males reared from Ericaphis scammelli on Vaccinium corymbosum; 23 VI 2015, 3 males reared from Ericaphis scammelli on Vaccinium corymbosum. United Kingdom, Scotland, 19 VI 2014, 9 females and 5 males reared from Ericaphis scammelli on Vaccinium corymbosum. Sweden, 


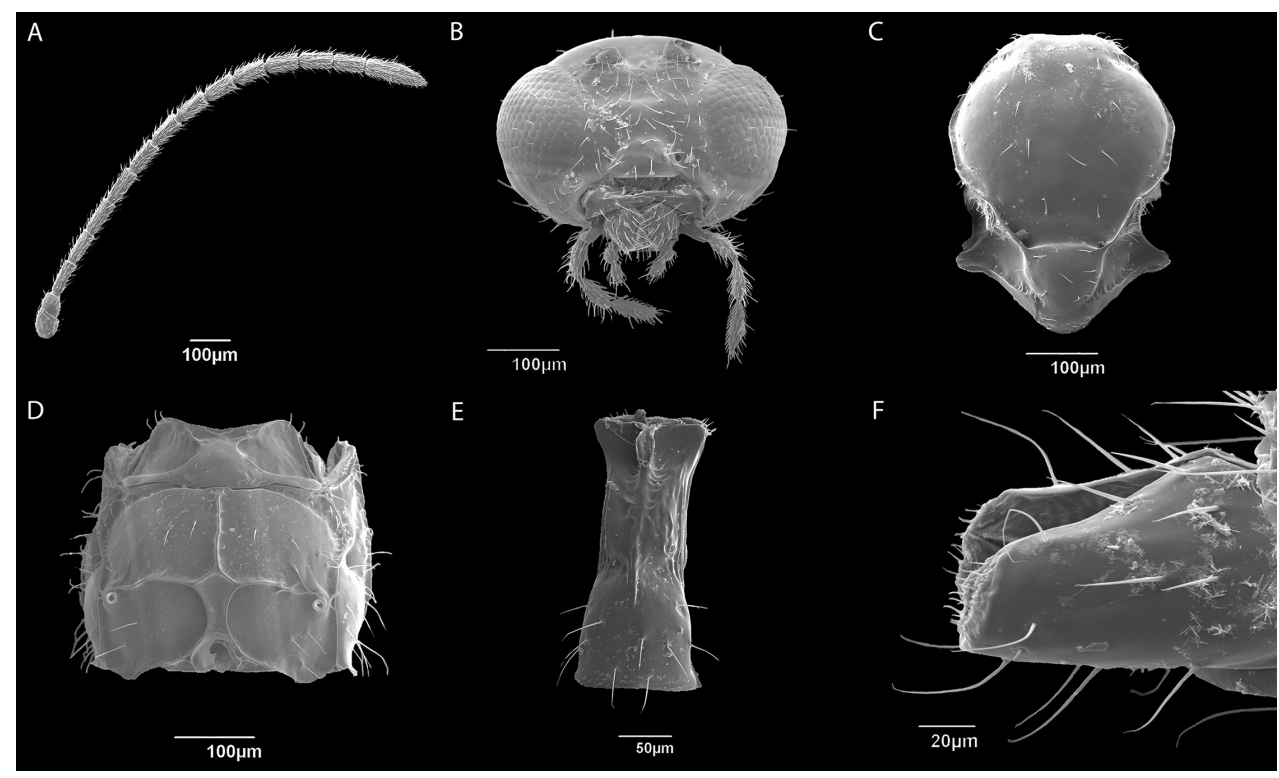

Figure I. Aphidius ericaphidis female: A antenna B head $\mathbf{C}$ mesonotum - dorsal aspect $\mathbf{D}$ propodeum dorsal aspect $\mathbf{E}$ petiole - dorsal aspect $\mathbf{F}$ ovipositor - lateral aspect.

Glemmingebro, Scania, 24 VI 2008, 1 female and 1 male from Ericaphis scammelli on Vaccinium corymbosum; 30 VI 2008, 5 females and 5 males from Ericaphis scammelli on Vaccinium corymbosum, greenhouse. Netherlands, Kootwijk, 8 VI 1965, 1 female from Ericaphis latifrons on Empetrum nigrum. France, Lognan (Hte-Savoie), 12 VIII 1968, 1 female and 1 male from Ericaphis latifrons on Vaccinium uliginosum.

\section{Molecular analysis of Aphidius ericaphidis}

Three barcoding sequences of $A$. ericaphidis originating from Scotland were compared with two sequences of $A$. ericaphidis from the USA and were determined to be identical, with no variable sites detected.

Topology of the phylogenetic tree shows clear separation of $A$. ericaphidis from other Aphidius species used in the analysis (Fig. 2). Though morphologically more similar to it than to the other Aphidius species, $A$. ericaphidis did not cluster with $A$. matricariae, and the mean K2P distance between the two species was $8.1 \%$ (Table 2). Divergence rates in relation to other species morphologically similar to $A$. ericaphidis or parasitizing E. scammelli were as follows: $A$. urticae $-8.9 \%$, A avenaphis $-10.4 \%$ and $A$. ervi- $8.3 \%$ (Table 2). Those distances are greater than what is considered to be enough for the separation of Aphidiinae species (Derocles et al. 2012, Tomanović et al. 2014). Thus, after morphological description, we here support the status of this taxon with molecular analysis. 


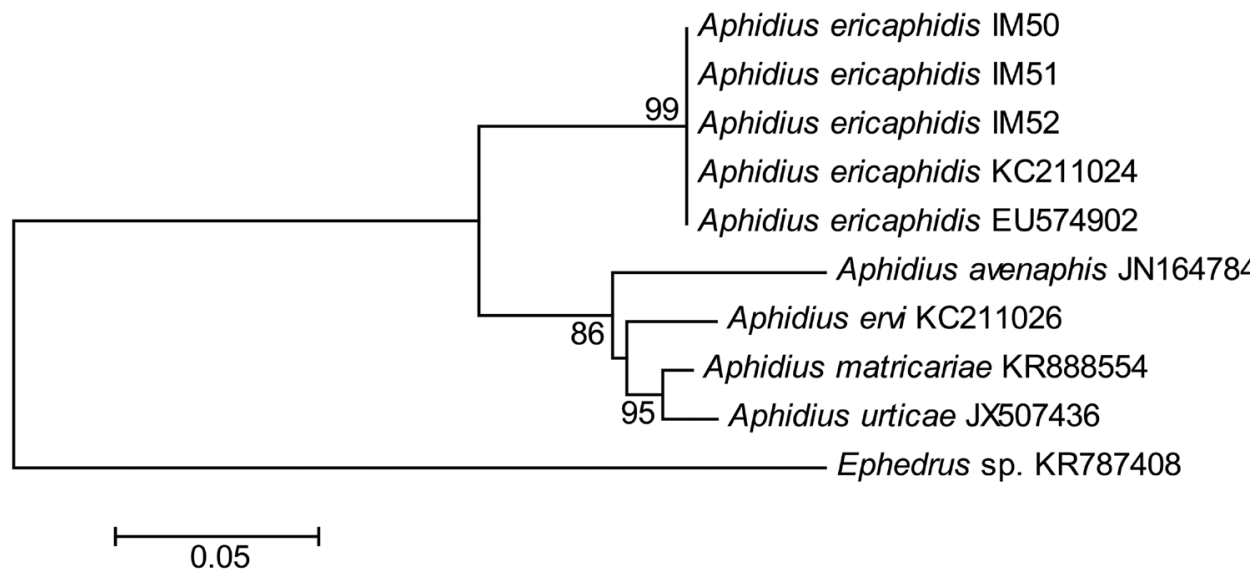

Figure 2. Phylogenetic tree based on COI sequences inferred by Maximum Likelihood (ML) method. Bootstrap values over $80 \%$ are shown.

Table 2. Mean K2P distances between COI sequences of Aphidius species used in this study.

\begin{tabular}{l|c|c|c|c}
\hline & A. ericaphidis & A. matricariae & A. urticae & A. avenaphis \\
\hline A. ericaphidis & & & & \\
\hline A. matricariae & 0.081 & & & \\
\hline A. urticae & 0.089 & 0.018 & & \\
\hline A. avenaphis & 0.104 & 0.058 & 0.063 & \\
\hline A. ervi & 0.083 & 0.034 & 0.037 & 0.065 \\
\hline
\end{tabular}

\section{Discussion}

Highbush blueberry production has been on the rise in the world, and as a consequence of increased international trade of planting material, plant pathogens and pests are also being spread to new areas. In the last 15 years, two exotic Vaccinium pathogens with North American origin (Monilinia vaccinii-corymbosi and $\mathrm{BlScV}$ ) were detected in Europe, and it is assumed that both were imported with plant material (Gosch 2003, Ciuffo et al. 2005, Munda 2011, Paduch-Cichal et al. 2011, Richert-Pöggeler et al. 2015). The situation is the same with at least two pest species, blueberry gall midge Dasineura oxycoccana and the aphid Ericaphis scammelli, which most likely also have a North American origin (Bosio et al. 1998, Barbagallo et al. 1998). Although E. scammelli (under different names) has been present in Europe for over half a century (Cœur d'acier et al. 2010), A. ericaphidis is its first parasitoid detected in Europe (in Serbia, Sweden, the Netherlands, France and the United Kingdom). While most alien Aphidiinae species reported in Europe were introduced intentionally as biocontrol agents (Roy et al. 2011, Petrović et al. 2013), for A. ericaphidis this is not the case. Some $A$. ericaphidis populations were most likely founded by specimens introduced accidentally with Vaccinium plant material "hitchhiking" in E. scammelli. This is the 
most obvious scenario for the records from Serbia and Sweden. Intensive research of Aphidiinae in Serbia has been ongoing for more than 20 years, and one of the main focuses has been on the Aphidiinae fauna of high mountain plants (including native Vaccinium species). Until recently (2015), there was no evidence of either E. scammelli or A. ericaphidis (Kavallieratos et al. 2004, Žikić et al. 2012). Both the aphid and the parasitoid were detected for the first time on a commercial $V$. corymbosum plantation with material imported from the Netherlands (probably originating from North America). Aphidius ericaphidis from E. scammelli/ V. corymbosum in a greenhouse in Sweden might also be a result of an accidental introduction from North America via blueberry nurseries in Germany. The same year when A. ericaphidis was recorded (2008), a detailed survey of aphids on blueberries (native and highbush plantations) was conducted, and the parasitoid was found only in one greenhouse situated about $30 \mathrm{~km}$ from the nearest forest woodland and surrounded by farmland (B. Nedstam unpubl.).

However, our revision of material from earlier collections from France and the Netherlands showed that the parasitoid has been present in Europe at least as long as E. scammelli (if not longer). At the time of the records, blueberry production in Europe wasn't as extensive as it is today, and the import of plants from North America was limited to a few countries. The record from France suggests that those populations of $A$. ericaphidis had enough time to spread and establish, especially since the record is from a native high mountain ecosystem (Vaccinium uliginosum/Ericaphis latifrons/ Aphidius ericaphidis).

The lack of any genetic differences shows that analysed European and North American populations of $A$. ericaphidis are very closely related. This can suggest that the analysed specimens were from a recent introduction or that they represent a species with no genetic differentiations based on the COI gene, as has been recorded before for some other Aphidius species (A. uzbekistanicus and A. avenaphis) (Tomanović et al. 2013).

Since molecular and morphological analyses of the target parasitoid populations revealed no significant differences, it might be concluded that $A$. ericaphidis is a member of the Holarctic forest tundra faunistic complex (Starý 1970) associated with different Ericaphis aphids in both Europe and North America. Although it is a very common parasitoid of Ericaphis in North America (at least in the Pacific Northwest) (Pike et al. 2011), in Europe it is quite rare, with only two records prior to 2008 (Starý et al. 1971, P. Starý unpubl.). There are two main factors contributing to the spread of $A$. ericaphidis in Europe during the last decade. The first one involves probable multiple introductions from North America with planting material and E. scammelli; the second one consists of a possible new adaptation of European populations of $A$. ericaphidis to this introduced aphid.

The current known host range of European populations of $A$. ericaphidis is similar to that of North American populations, with the vast majority of records reported from Ericaphis aphids (Pike et al. 2011). Although three out of 10 parasitoid species (Aphidius ervi, Aphidius matricariae and Lysiphlebus testaceipes) that parasitize E. scammelli in North America also occur in Europe, A. ericaphidis is the only species recorded that successfully parasitizes E. scammelli (Suppl. material 1: Table S1.). In this respect, there is potential 
in biological control of these aphids, which can serve as vectors of the blueberry scorch virus if populations are left uncontrolled. Since the virus has spread to Europe recently, the possibility of using $A$. ericaphidis as a biocontrol agent should be investigated thoroughly. It can then be added to the list of already tested European Aphidiinae species for which the ability to control E. scammelli in field conditions has been determined (Dassonville et al. 2013). Of course, this requires very careful additional testing, since there are several parasitoid species that were introduced as biocontrol agents and then became widespread (Roy et al. 2011) and broadened their host range in non-native areas (Mitrović et al. 2013, Petrović et al. 2013). On the other hand, Pike et al. (2011) report rare occurrences of parasitization of Macrosiphum parvifolii Richards by A. ericaphidis, which implies its potential to parasitize other species.

The current distribution of $A$. ericaphidis and that of its host Ericaphis scammelli in Europe are most likely much broader than those recorded so far, and field surveys should therefore be conducted in all Vaccinium growing areas to monitor the spread of A. ericaphidis in Europe and possible changes of its host range.

\section{Acknowledgements}

This study was supported by the Ministry of Education, Science and Technological Development of the Republic of Serbia (project III43001). The participation of P. Starý was funded by the Institute of Entomology, while that of B. Nedstam (ret.) was funded by the Swedish Board of Agriculture. We thank the Viridaxis company for the loan of A. ericaphidis specimens from Scotland.

\section{References}

Barbagallo S, Bosio G, Brussino G, Scarpelli F (1998) Gli afidi infestanti le colture del mirtillo gigante americano in Italia. Informatore Fitopatologico 48: 65-71. http://www.verdeepaesaggio.it/2008/02/04/afidi-infestanti-le-colture-del-mirtillo-gigante-americano-in-italia/

Blackman RL, Eastop VF (1984) Aphids on the world's crops: an identification and information guide. Wiley, New York, 466 pp.

Bosio G, Bogetti C, Brussino G, Gremo F, Scarpelli F (1998) Dasineura oxycoccana, a new pest of blueberry (Vaccinium corymbosum) in Italy. Informatore Fitopatologico 11: 36-41.

Bristow PR, Martin RR, Windom GE (2000) Transmission, field spread, cultivar response, and impact on yield in highbush blueberry infected with Blueberry scorch virus. Phytopathology 90(5): 474-479. http://dx.doi.org/10.1094/PHYTO.2000.90.5.474

Ciuffo M, Pettiti D, Gallo S, Masenga V, Turina M (2005) First report of Blueberry Scorch Virus in Europe. Plant Pathology 54: 565. http://dx.doi.org/10.1111/j.1365-3059.2005.01198.x

Clarke S (2016) Blueberries in the European Union. Agriculture and Agri-Food Canada. http:// www.agr.gc.ca/resources/prod/Internet-Internet/MISB-DGSIM/ATS-SEA/PDF/6719eng.pdf 
Cœur d'acier A, Pérez Hidalgo N, Petrović-Obradović O (2010) Aphids (Hemiptera, Aphididae). In: Roques A, Kenis M, Lees D, Lopez-Vaamonde C, Rabitsch W, Rasplus JY, Roy D (Eds) Alien terrestrial arthropods of Europe. Biorisk 4(1): 435-474. http://dx.doi. org/10.3897/biorisk.4.57

Coville FV (1910) Experiments in blueberry culture. U.S. Department of Agriculture Bulletin 193.

Dassonville N, Thiellemans T, Gosset V (2013) FresaProtect and BerryProtect: mixes of parasitoids to control all common aphid species on protected soft fruit crops: Product development and case studies from three years of experience. Aspects of Applied Biology 119: 79-81. http://www.viridaxis.com/wp-content/uploads/emr_case_studies.pdf

Derocles SA, Le Ralec A, Plantegenest M, Chaubet B, Cruaud C, Cruaud A, Rasplus JY (2012) Identification of molecular markers for DNA barcoding in the Aphidiinae (Hymenoptera: Braconidae). Molecular Ecology Resources 12: 197-208. http://dx.doi.org/10.1111/ j.1755-0998.2011.03083.x

EPPO [European and Mediterranean Plant Protection Organisation] (2005) First report of Blueberry scorch carlavirus in Europe: addition to the EPPO Alert List. https://gd.eppo. int/reporting/article-1433 [accessed on 10.1.2017]

EPPO [European and Mediterranean Plant Protection Organisation] (2016) Blueberry scorch virus (BLSCV0). https://gd.eppo.int/taxon/BLSCV0/distribution [accessed on 10.1.2017]

Food and Agriculture Organization of the United Nations (2012) FAOSTAT Database. FAO, Italy, Rome. http://faostat3.fao.org/home/E [January 25, 2017]

Folmer O, Black M, Hoeh W, Lutz R, Vrijenhoek R (1994) DNA primers for amplification of mitochondrial cytochrome c oxidase subunit I from diverse metazoan invertebrates. Molecular Marine Biology and Biotechnology 3: 294-299. https://www.ncbi.nlm.nih.gov/ pubmed/7881515

Foottit RG, Maw HEL, von Dohlen CD, Hebert PDN (2008) Species identification of aphids (Insecta: Hemiptera: Aphididae) through DNA barcodes. Molecular Ecology Resources 8: 1189-1201. http://dx.doi.org/10.1111/j.1755-0998.2008.02297.x

Gosch C (2003) Monilinia vaccinii-corymbosi on Highbush Blueberries (Vaccinium corymbosum L.): Also in Europe! European Journal of Horticultural Science 68(5): 238-241.

Heermann W (1932) Witere Beiträge zur Heidelbeerzüchtung. Der Züchter 4(1): 1-8.

Hudgins E (2000) Survey of Blueberry Scorch Virus in highbush blueberries in British Columbia. Canadian Plant Disease Survey 81:144-147.

Kavallieratos NG, Tomanović Ž, Starý P, Athanassiou CG, Sarlis GP, Petrović O, Niketić M, Veroniki MA (2004) A survey of aphid parasitoids (Hymenoptera: Braconidae: Aphidiinae) of Southeastern Europe and their aphid-plant associations. Applied Entomology and Zoology 39(3): 527-563. http://dx.doi.org/10.1303/aez.2004.527

Kimura M (1980) A simple method for estimating evolutionary rate of base substitutions through comparative studies of nucleotide sequences. Journal of Molecular Evolution 16: 111-120. http://dx.doi.org/10.1007/bf01731581

Mathur S, Raworth DA, Pike KS, Fitzpatrick SM (2013) Diagnostic molecular markers to detect and identify primary parasitoids (Hymenoptera: Braconidae) of Ericaphis fimbriata on highbush blueberry. Journal of the Entomological Society of British Columbia 110: 19-26. http://journal.entsocbc.ca/index.php/journal/article/view/289 
Martin RR, Bristow PR (1988) A Carlavirus associated with Blueberry Scorch Disease. Phytopathology 78(12): 1636-1640. http://dx.doi.org/10.1094/Phyto-78-1636

Martin RR, Polashock JJ, Tzanetakis IE (2012) New and emerging viruses of blueberry and cranberry. Viruses 4: 2831-2852. http://dx.doi.org/10.3390/v4112831

Mitrović M, Petrović A, Kavallieratos NG, Starý P, Petrović-Obradović O, Tomanović Ž, Vorburger C (2013) Geographic structure with no evidence for host-associated lineages in European populations of Lysiphlebus testaceipes, an introduced biological control agent. Biological Control 66(3): 150-158. http://dx.doi.org/10.1016/j.biocontrol.2013.05.007

Munda A (2011) Monilinia pathogens of cultivated and native Vaccinium species in Slovenia. Acta Agriculturae Slovenica 97: 99-104. http://dx.doi.org/10.2478/v10014-011-0005-9

Nedstam B (2008) Some pest problems and solutions in Swedish organic greenhouse production. Integrated Control in Protected Crops, Temperate Climate, IOBC/wprs Bulletin 32: 155157. http://www.iobc-wprs.org/pub/bulletins/iobc-wprs_bulletin_2008_32.pdf\#page=171

Nieto Nafria JM (2013) Fauna Europaea: Hemiptera, Aphididae. Fauna Europaea version 2.6.2. http://www.faunaeur.org

Paduch-Cichal E, Kalinowska E, Chodorska M, Sala-Rejczak K, Nowak B (2011) Detection and identification of viruses of highbush blueberry and cranberry using serological ELISA test and PCR technique. Acta Scientiarum Polonorum, Hortorum Cultus 10(4): 201-215. http://wydawnictwo.up.lublin.pl/acta/hortorum_cultus/2011/4/18.pdf

Pansa MG, Tavella L (2008) Aphid population dynamics on highbush blueberry in relation to the spread of Blueberry scorch virus in Piedmont (NW Italy). Bulletin of Insectology 61(1): 205-206. http://www.bulletinofinsectology.org/pdfarticles/vol61-2008-205-206pansa.pdf

Petrović A, Mitrović M, Starý P, Petrović-Obradović O, Žikić V, Tomanović Ž, Vorburger C (2013) Lysiphlebus orientalis (Hymenoptera, Braconidae), a new invasive aphid parasitoid in Europe - evidence from molecular markers. Bulletin of Entomological Research 103: 451-457. http://dx.doi.org/10.1017/S0007485313000035

Pike KS, Starý P, Graf G, Raworth DA, Mathur S, Tanigoshi LK, Murray T (2011) A new Aphidius Nees (Hymenoptera, Braconidae, Aphidiinae) of Ericaphis fimbriata (Richards) (Hemiptera, Aphididae) and key to parasitoids of blueberry aphid in the Pacific Northwest. Zootaxa 2802: 58-62. http://www.mapress.com/j/zt/article/view/10775

Pliszka K (1997) Overview on Vaccinium production in Europe. Acta Horticulturae 446: 49-52. http://dx.doi.org/10.17660/ActaHortic.1997.446.5

Prior RNB (1971) Some notes on new or uncommon aphids recently found in Britain. Zoological Journal of the Linnaean Society 50: 397-430. http://dx.doi.org/10.1111/ j.1096-3642.1971.tb00768.x

Raworth DA, Pike KS, Tanigoshi LK, Mathur S, Graf G (2008) Primary and secondary parasitoids (Hymenoptera) of aphids (Hemiptera: Aphididae) on blueberry and other Vaccinium in the Pacific Northwest. Community and Ecosystem Ecology 37(2): 472-477. http://dx.doi. org/10.1093/ee/37.2.472

Richert-Pöggeler KR, Turhal AK, Schuhmann S, Maaß C, Blockus S, Zimmermann E, Eastwell KC, Martin RR, Lockhart B (2015) Carlavirus biodiversity in horticultural host plants: Effi- 
cient virus detection and identification combining electron microscopy and molecular biology tools. Acta Horticulturae 1072: 37-45. http://dx.doi.org/10.17660/ActaHortic.2015.1072.3

Roy HE, Roy DB, Roques A (2011) Inventory of terrestrial alien arthropod predators and parasites established in Europe. BioControl 56: 477-504. http://dx.doi.org/10.1007/s10526011-9355-9

Starý P (1970) Biology of aphid parasitoids (Hymenoptera, Aphidiidae) with respect to integrated control. Dr. W. Junk, The Hague, 1-643.

Starý P, Remaudière G, Leclant F (1971) Les Aphidiidae (Hym.) de France et leurs hôtes (Hom. Aphididae): description d'espèces nouvelles, ècologie, lutte biologique. Entomophaga, Mémoire Hors-série 5: 1-72.

Tamura K, Peterson D, Peterson N, Stecher G, Nei M, Kumar S (2011) MEGA5: Molecular evolutionary genetics analysis using maximum likelihood, evolutionary distance and maximum parsimony methods. Molecular Biology and Evolution 28: 2731-2739. http:// dx.doi.org/10.1093/molbev/msr121

Tomanović Ž, Kos K, Petrović A, Starý P, Kavallieratos NG, Žikić V, Jakše J, Trdan S, Ivanović A (2013) The relationship between molecular variation and variation in the wing shape of three aphid parasitoid species: Aphidius uzbekistanicus Luzhetzki, Aphidius rhopalosiphi De Stefani Perez and Aphidius avenaphis (Fitch) (Hymenoptera: Braconidae: Aphidiinae). Zoologischer Anzeiger 252(1): 41-47. https://doi.org/10.1016/j.jcz.2012.03.003

Tomanović Ž, Petrović A, Mitrović M, Kavallieratos NG, Starý P, Rakhshani E, Rakhshanipour M, Popović A, Shukshuk AH, Ivanović A (2014) Molecular and morphological variability within the Aphidius colemani group with redescription of Aphidius platensis Brethes (Hymenoptera: Braconidae: Aphidiinae). Bulletin of Entomological Research 104: 552-565. http://dx.doi.org/10.1017/S0007485314000327

Žikić V, Ilić-Milošević M, Stanković S, Petrović A, Petrović-Obradović O, Kavallieratos N, Starý P, Tomanović Ž (2012) Aphidiinae (Hymenoptera: Braconidae) of Serbia and Montenegro - tritrophic interactions. Acta Entomologica Serbica 17(1/2): 83-105. http:// www.eds.org.rs/AES/Vol17/Zikic\%20et\%20al\%20(2012).pdf

\section{Supplementary material I}

\section{Table S1. Parasitoids of Ericaphis aphids from North America and Europe}

Authors: Andjeljko Petrović, Jelisaveta Čkrkić, Aiman Jamhour, Olivera PetrovićObradović, Milana Mitrović, Petr Starý, Barbro Nedstam, Željko Tomanović

Data type: species data

Copyright notice: This dataset is made available under the Open Database License (http://opendatacommons.org/licenses/odbl/1.0/). The Open Database License $(\mathrm{ODbL})$ is a license agreement intended to allow users to freely share, modify, and use this Dataset while maintaining this same freedom for others, provided that the original source and author(s) are credited.

Link: https://doi.org/10.3897/jhr.57.12517.suppl1 